Article

\title{
Physical and Morphological Characterization of Chitosan/Montmorillonite Films Incorporated with Ginger Essential Oil
}

\author{
Victor Gomes Lauriano Souza ${ }^{1, * \mathbb{C}}$, João Ricardo Afonso Pires ${ }^{1}{ }^{\circledR}$, Carolina Rodrigues ${ }^{1}$, \\ Patricia Freitas Rodrigues ${ }^{2}\left(\mathbb{D}\right.$, Andréia Lopes ${ }^{2}$, Rui Jorge Silva ${ }^{2}$ (D) Jorge Caldeira ${ }^{3,4,5}$, \\ Maria Paula Duarte ${ }^{1}$, Francisco Braz Fernandes ${ }^{2}$, Isabel Maria Coelhoso ${ }^{3} \mathbb{D}$ and \\ Ana Luisa Fernando $1, *$ ib \\ 1 MEtRICs, Departamento de Ciências e Tecnologia da Biomassa, Faculdade de Ciências e Tecnologia, FCT, \\ Universidade NOVA de Lisboa, Campus de Caparica, 2829-516 Caparica, Portugal; \\ jr.pires@campus.fct.unl.pt (J.R.A.P.); cpe.rodrigues@campus.fct.unl.pt (C.R.); mpcd@fct.unl.pt (M.P.D.) \\ 2 CENIMAT/I3N, Departamento de Ciência dos Materiais, Faculdade de Ciências e Tecnologia, Universidade \\ NOVA de Lisboa, Campus de Caparica, 2829-516 Caparica, Portugal; pf.rodrigues@campus.fct.unl.pt (P.F.R.); \\ keyalopes@gmail.com (A.L.); rjcs@fct.unl.pt (R.J.S.); fbf@fct.unl.pt (F.B.F.) \\ 3 LAQV-REQUIMTE, Departamento de Química, Faculdade de Ciências e Tecnologia, Universidade Nova de \\ Lisboa, 2829-516, Campus de Caparica, 2829-516 Caparica, Portugal; fjfc@fct.unl.pt (J.C.); \\ imrc@fct.unl.pt (I.M.C.) \\ 4 UCIBIO-REQUIMTE, Departamento de Química, Faculdade de Ciências e Tecnologia, Universidade Nova \\ de Lisboa, 2829-516, Campus de Caparica, 2829-516 Caparica, Portugal \\ 5 Centro de investigação interdisciplinar Egas Moniz, Instituto Universitário Egas Moniz, Campus \\ Universitário, Quinta da Granja, Monte de Caparica, 2829 - 511 Caparica, Portugal \\ * Correspondence: v.souza@campus.fct.unl.pt (V.G.L.S.); ala@fct.unl.pt (A.L.F.)
}

Received: 11 October 2019; Accepted: 24 October 2019; Published: 26 October 2019

\begin{abstract}
Novel bionanocomposite films of chitosan/montmorillonite (CS/MMT) activated with ginger essential oil (GEO) were produced and characterized in terms of their physical and morphological properties. The homogenization process led to a good interaction between the chitosan and the nanoparticles, however the exfoliation was diminished when GEO was incorporated. Film glass transition temperature did not statistically change with the incorporation of either MMT or GEO, however the value was slightly reduced, representing a relaxation in the polymer chain which corroborated with the mechanical and barrier properties results. Pristine chitosan films showed excellent barrier properties to oxygen with a permeability of $0.184 \times 10^{-16} \mathrm{~mol} / \mathrm{m} \cdot \mathrm{s} \cdot$ Pa being reduced to half $\left(0.098 \times 10^{-16} \mathrm{~mol} / \mathrm{m} \cdot \mathrm{s} \cdot \mathrm{Pa}\right)$ when MMT was incorporated. Although the incorporation of GEO increased the permeability values to $0.325 \times 10^{-16} \mathrm{~mol} / \mathrm{m} \cdot \mathrm{s} \cdot$ Pa when $2 \%$ of GEO was integrated, this increment was smaller with both MMT and GEO $\left(0.285 \times 10^{-16} \mathrm{~mol} / \mathrm{m} \cdot \mathrm{s} \cdot \mathrm{Pa}\right)$. Bionanocomposites also increased the UV light barrier. Thus, the produced bioplastics demonstrated their ability to retard oxidative processes due to their good barrier properties, corroborating previous results that have shown their potential in the preservation of foods with high unsaturated fat content.
\end{abstract}

Keywords: biobased polymers; chitosan; nanotechnology

\section{Introduction}

The development of food packaging is currently focused on the use of polymers usually derived from plants, i.e., bioplastics with an eco-friendly and sustainable approach, an alternative to non-biodegradable materials from non-renewable sources (petroleum-based materials) [1-4]. 
These materials can be divided into four main classes, namely: proteins, polysaccharides, lipids and composites [1]. Polysaccharides are highlighted due to their good oxygen barrier related to their well-ordered hydrogen bonded network shape, which may enhance the protection conferred to food packaged against the oxidation process $[1,5,6]$. However, the weaker mechanical properties and water vapor barrier limit their use, and through the combination with other polymers (i.e., bilayers) or the incorporation of nanofillers, such as montmorillonite, this limitation can be overcome $[5,7,8]$. Chitosan (poly- $\beta(1,4)$-2-amino-2-deoxy-D-glucose), the second most abundant polysaccharide in nature, obtained from the deacetylation of chitin, is a biodegradable biopolymer with potential to be use as food-grade films and coatings [9-16].

Aiming to reduce the use of synthetic chemical additives, the food industry has increased its interest in the research of natural preservatives, i.e., food components or extracts with antimicrobial and antioxidant properties, with less harmful effect to human health [17-20]. Moreover, food-borne microbial outbreaks have driven the industry and the scientific community to search for innovative ways to inhibit microbial growth in foods while maintaining quality, freshness, and safety [21]. The use of packaging is an option to provide an increased margin of safety and quality, as the next generation of food packaging will include materials with antimicrobial and antioxidant properties that are capable of protecting the food packaged, extending its shelf life [7,21,22]. Essential oils (EOs) are a good example of such materials suitable to be used in the production of this next generation of food packaging [23]. EOs are natural substances extracted from different parts (i.e., roots, bark, or leaves) of a variety of plants, many of them already used in traditional culinary (e.g., rosemary, thyme, sage, ginger, citronella) [18]. Despite the remarkable preservative properties of these components, their use as food additives is discouraged by the strong aroma they confer to the foodstuff when directly incorporated into the food matrix $[17,18,22,24]$. Thus, the incorporation of EOs into food packaging material may solve this organoleptic problem, enabling their application to the preservation of food [24]. When incorporated into polymeric matrices, the amount necessary is diminished as the migration occurs gradually towards the food surface, where the food spoilage takes place $[25,26]$.

In our previous works, different natural extracts, either essential oils or hydro-alcoholic extracts from a variety of plants, were incorporated into chitosan $[17,27]$. The films produced were characterized in terms of their antioxidant activity [17] and physical properties [27]. Within the different essential oils tested, it was concluded that rosemary essential oil (REO) and ginger essential oil (GEO) presented the best active properties [17], thus, novel bionanocomposites incorporated with such EOs were produced and nanoreinforced with montmorillonite (MMT). As novel materials, it is crucial to understand how the incorporation of MMT and the essential oil would interfere in the functional and bioactive properties of the film. In vitro and in situ activity of CS/MMT activated with different levels of GEO have been investigated [28] and those bionanocomposites have proven to have good antimicrobial and antioxidant activity, being able to extend the shelf-life of fresh poultry meat, a foodstuff with high unsaturated fat content. As the ultimate purpose of the film is to be used as primary packaging for food products, information on its mechanical and barrier properties, not studied yet for these novel materials, should also be understood. Thus, this work is focused on the characterization of bionanocomposites incorporated with GEO reinforced with MMT in terms of their physical, morphological, and barrier properties.

\section{Materials and Methods}

\subsection{Materials and Reagents}

Commercial high molecular weight (31-37 kDa) chitosan (poly(D-glucosamine)) with $75 \%$ of deacetylation and ethanol absolute were purchased from Sigma Aldrich (Germany). Sodium montmorillonite $\left(\right.$ Cloisite ${ }^{\circledR} \mathrm{Na}^{+}$) was kindly supplied by BYK Additives \& Instruments (USA). Ginger essential oil (EO), with food grade classification, was acquired from Biover (Belgium). Glacial acetic acid, glycerol, calcium nitrate $\left(\mathrm{Ca}\left(\mathrm{NO}_{3}\right)_{2}\right)$, sodium bromide $(\mathrm{NaBr})$, potassium acetate $\left(\mathrm{CH}_{3} \mathrm{COOK}, 99 \%\right.$ purity), and tween 80 
(polyethylene glycol sorbitan monolaurate) were purchased from Alfa Aesar (Germany). Sodium chloride $(\mathrm{NaCl})$ was obtained from PanReac (Spain). All chemicals were of analytical reagent grade and were used as purchased. The water was purified using the Milli-Q system (Millipore, USA).

\subsection{Bionanocomposites Production}

The composite films were prepared according to Souza et al. (2018) [28]. Briefly, to prepare the film-forming dispersion (FFD), 1.5\% (w/v) of chitosan was dissolved in 1\% $(v / v)$ of glacial acetic acid solution under continuous agitation for $24 \mathrm{~h}$ at room temperature. Then, $30 \%$ ( $w / w$ chitosan) of glycerol was added as a plasticizer in all treatments. At this stage, GEO in the levels tested $(0 \% ; 0.5 \% ; 1 \%$ or $2 \% v / v$ FFD) and $0.2 \%$ ( $w / v$ in essential oil) of the emulsifier tween 80 were added to the system. Subsequently, an agitation cycle consisting of $5 \mathrm{~min}$ agitation with ultraturrax $(15,000 \mathrm{rpm})\left(\mathrm{IKA}{ }^{\circledR} \mathrm{T} 18\right.$, Staufen, Germany) followed by $15 \mathrm{~min}$ degasification in an ultrasound bath (360 W) (Selecta, Spain) was carried out. The resulting dispersion was then casted in glass molds $(18 \times 25 \mathrm{~cm})$ and let to dry naturally for approximately $48-72 \mathrm{~h}$. This was the procedure used to produce chitosan films without the incorporation of the nanoreinforcement (MMT). To produce the bionanocomposites, $2.5 \%$ ( $w / w$ chitosan) of MMT was added to the FFD already containing the glycerol, and two extra agitation steps (same as described before) were added before the incorporation of GEO and tween 80 , and the third and final agitation cycle was carried out, followed by the casting. These extras steps were added to supply energy to the system and promote the exfoliation of the MMT. Dried films were peeled and stored protected from light in a desiccator containing saturated calcium nitrate solution at $25{ }^{\circ} \mathrm{C}$ and $50 \%$ relative humidity, monitored with a thermohygrometer, until evaluation.

\subsection{Film Characterization}

\subsubsection{X-ray Diffraction (XRD)}

X-ray diffraction is one of the techniques used to study the structure of MMT within the polymer, being indicative of a succeeded exfoliation process, thus a tool to understand whether the nanomaterial reinforced the biopolymer or not. Diffractograms of the films were obtained using a DMAX-IIIC diffractometer (Rigaku Industrial Corporation, Tokyo, Japan), equipped with $\mathrm{CuK} \alpha(\lambda=1.5418 \AA)$ radiation $(40 \mathrm{kV}, 30 \mathrm{~mA}), 2 \theta$ angle range $5^{\circ}$ to $40^{\circ}$, a scanning rate of $2^{\circ} / \mathrm{min}$ and a sampling interval of $0.02^{\circ}(2 \theta)$. The interlamellar distances (d001) were calculated using Bragg's Law (Equation (1)) [22].

$$
\operatorname{sen} \theta=\frac{n \lambda}{2 d}
$$

where $\lambda$ is the radiation wavelength, $d$ is the interlamellar distance in $\AA, n$ is diffraction number $(n=1)$, and $\theta$ is the measured diffraction angle.

\subsubsection{Attenuated Total Reflectance Fourier Transform Infrared Spectroscopy (ATR-FTIR)}

Attenuated total reflectance Fourier transform infrared spectra of the bionanocomposites were collected using a FTIR spectrometer (model PerkinElmer spectrum Two, Perkin Elmer, Waltham, MA, USA) from 4000 to $650 \mathrm{~cm}^{-1}$ at a $1 \mathrm{~cm}^{-1}$ resolution [17].

\subsubsection{Morphological Characterization: Scanning Electron Microscopy (SEM)}

To analyze the bionanocomposite morphology, scanning electron microscopy micrographs were performed from the surface and cross-section of the following samples: pristine chitosan film, chitosan + MMT; chitosan $+2 \%$ GEO, and chitosan + MMT $+2 \%$ GEO. The images were obtained from a Zeiss instrument (Model DSM 962, Oberkochen, Germany) under vacuum, accelerated at $3 \mathrm{kV}$. The samples were fixed with a double adhesive coated carbon tape on aluminium stubs and covered with gold palladium using a sputter coater. Cross-section images were carried out in samples previously submitted to fractions after contact with liquid nitrogen. 


\subsubsection{Thermal Properties}

Thermal properties were studied through differential scanning calorimetry (DSC) and thermogravimetric analysis (TGA).

The glass transition temperature ( $\mathrm{Tg}$ ) of the samples was determined using DSC model $204 \mathrm{~F} 1$ Phoenix ${ }^{\circledR}$ (Netzsch, Selb, Germany). Approximately $10 \mathrm{mg}$ of each sample were sealed in a standard aluminum pan and thermal cycle was performed from $20^{\circ} \mathrm{C}$ to $350{ }^{\circ} \mathrm{C}$ at a constant heating rate of $20^{\circ} \mathrm{C} / \mathrm{min}$ under nitrogen atmosphere (flow rate of $50 \mathrm{~mL} / \mathrm{min}$ ) [29].

The thermal stability of bionanocomposites was characterized using a simultaneous thermal analyzer (PerkinElmer, Model STA 6000, Germany). A sample from each treatment (approximately $10 \mathrm{mg}$ ) was heated to $900{ }^{\circ} \mathrm{C}$ at a rate of $10^{\circ} \mathrm{C} / \mathrm{min}$ and maintained in isotherm during $3 \mathrm{~min}$ under nitrogen atmosphere [30]. Compound degradation temperatures and percentages were determined from the first derivative of the weight loss curve percent (DTGA) versus temperature.

\subsubsection{Thickness and Mechanical Properties}

Film thickness was measured using a Mitutoyo digital micrometer (Mitutoyo, Kawasaki, Japan), with $0.001 \mathrm{~mm}$ precision, on ten randomly points of each sample [22].

Mechanical properties were determined according to ASTM D882-12 (2012) [31]. Elastic modulus $(\mathrm{EM})$, tensile strength (TS), and percentage of elongation at break (EAB) were measured from the tensile testing of five strips of each film with dimensions $150 \mathrm{~mm}$ wide and $25.4 \mathrm{~mm}$ long. The samples were mounted in the tensile grips with a $0.5 \mathrm{kN}$ load cell (Autograph Shimadzu, Sydney, Australia), with $50 \mathrm{~mm}$ initial gauge length and stretched at a cross-head speed of $50 \mathrm{~mm} / \mathrm{min}$ until breakage.

\subsubsection{Optical Properties}

To calculate optical parameters chroma $\left(c^{*}\right)$ and Hue angle (hue), CIE-L*a*b* coordinates ( $\mathrm{L}^{*}$ indicates black $(0)$ to white $(100)$; $\mathrm{a}^{*}$ indicates red $(+)$ to green $(-)$ and $\mathrm{b}^{*}$ indicates yellow $(+)$ to blue (-)) were measured from the bionanocomposites using a colorimeter CR 410 (Minolta Co., Tokyo, Japan) with a $10 \mathrm{~mm}$ diameter window and D65 illuminant $/ 10^{\circ}$ observer. The measurements were taken on a white background standard and the equations used are the following [32]:

$$
\begin{gathered}
c^{*}=\left(a^{* 2}+b^{* 2}\right)^{1 / 2} \\
\text { hue }=\arctan \left(\frac{b^{*}}{a^{*}}\right) x \frac{180}{\pi}, \text { for } a^{*}>0 \text { and } b^{*}>0 \\
\text { hue }=\arctan \left(\frac{b^{*}}{a^{*}}\right) x \frac{180}{\pi}+180, \text { for } a^{*}<0 \\
\text { hue }=\arctan \left(\frac{b^{*}}{a^{*}}\right) x \frac{180}{\pi}+360, \text { for } a^{*}>0 \text { and } b^{*}<0
\end{gathered}
$$

Film opacity was also determined by direct reading of the absorbance of rectangular samples at $600 \mathrm{~nm}$ using a UV-vis spectrophotometer (Model Spekol 1500, Analytikjena, Germany) and calculated according to Equation (6) [33].

$$
\operatorname{Opacity}\left(\mathrm{mm}^{-1}\right)=\frac{\text { absorbance } 600 \mathrm{~nm}}{\text { sample thickness }(\mathrm{mm})}
$$

Finally, film transparency was obtained from spectrum scans (from 190 to $900 \mathrm{~nm}$ ) using a UV-vis spectrophotometer of each film specimen. Air was used as reference and the results were expressed as a percentage of transmittance [34]. 


\subsubsection{Contact Angle (CA)}

Contact angle (CA) was measured using a goniometer (KSV Instruments Ltd., CAM 100, Finland) with the software KSV CAM 100 at room temperature $\left(25 \pm 2{ }^{\circ} \mathrm{C}\right)$ on the bionanocomposites produced. Film hydrophilic character was evaluated from water drop contact angles with their upper surface [5].

\subsubsection{Solubility and Swelling Degree}

The solubility in water (g/100 $\mathrm{g}$ of film) and the swelling degree $(\mathrm{g} / 100 \mathrm{~g}$ of film) were determined according to Souza et al. (2017) [27]. Briefly, film specimens were cut into a rectangle $(2 \times 2 \mathrm{~cm})$ and weighted (precision $0.0001 \mathrm{~g}$ ) in an analytical balance (Mettler Toledo AB204, Switzerland), obtaining the initial weight (M1); then samples were dried at $70{ }^{\circ} \mathrm{C}$ for $24 \mathrm{~h}$ in a natural conventional oven (WTB binder, Germany), and were weighted to obtain the initial dry mass (M2). Subsequently, samples were placed in Petri dishes containing $30 \mathrm{~mL}$ of Milli-Q water and stored for $24 \mathrm{~h}$ at room temperature $\left(25 \pm 2{ }^{\circ} \mathrm{C}\right)$, in order to allow the swelling process. After this contact period, the specimens were superficially dried with filter paper and weighted (M3) again. The residual film specimens were dried in an oven at $70{ }^{\circ} \mathrm{C}$ for $24 \mathrm{~h}$ to determine the final dry mass (M4). Two measurements from each film sample were taken, and the parameters calculate according to Equations (7) and (8).

$$
\begin{gathered}
\% \text { Solubility }\left(\frac{g}{100 g} \text { of film }\right)=\frac{\left(M_{2}-M_{4}\right)}{M_{2}} \times 100 \\
\% \text { Swelling degree }\left(\frac{g}{100 g} \text { of film }\right)=\frac{\left(M_{3}-M_{2}\right)}{M_{2}} \times 100
\end{gathered}
$$

\subsubsection{Water Vapor Permeability (WVP)}

The WVP (mol/m.s.Pa) was determined gravimetrically at $30^{\circ} \mathrm{C}$, based on the method described by Ferreira et al. (2016) [5]. The tested films were sealed on the top of $45 \mathrm{~mm}$ diameter glass cells containing $8 \mathrm{~mL}$ of saturated $\mathrm{NaCl}$ solution (relative humidity $(\mathrm{RH})=76.9 \%$ ) and placed in a desiccator with saturated potassium acetate solution ( $\mathrm{RH}=22.5 \%$ ) equipped with a fan to promote air circulation and maintain constant driving force. Temperature and the relative humidity were monitored with a thermohygrometer (Vaisala, Finland). The water transferred through the film and absorbed by the desiccant was determined from weight loss of the permeation cell (measured every $1 \mathrm{~h}$ during $10 \mathrm{~h}$ ), and the WVP calculated by following equation (Equation (9)):

$$
\mathrm{WVP}=\frac{\mathrm{N}_{\mathrm{W}} \times \delta}{\Delta P_{\text {w.eff }}}
$$

where $\mathrm{Nw}\left(\mathrm{mol} / \mathrm{m}^{2} \cdot \mathrm{s}\right)$ is the water vapour flux, $\delta(\mathrm{m})$ is the film thickness and $\Delta P_{w . e f f}(\mathrm{~Pa})$ is the effective driving force. Results are the average \pm standard deviation of the three replicates analyzed.

\subsubsection{Oxygen Permeability (OP)}

The OP was determined in a stainless steel cell with two identical chambers separated by the tested film $[5,35]$. Tested films were previously equilibrated at $30^{\circ} \mathrm{C}$ and relative humidity of $55 \% \pm 5 \%$ (desiccator containing saturated sodium bromide solution). The $\mathrm{OP}$ was assessed by pressurizing one of the chambers (feed) up to 0.7 bar with pure oxygen (99.999\% purity) (Praxair, Spain), followed by the measurement of the pressure change in both chambers over time, using two pressure transducers (Jumo, Model 404327, Germany). The system was kept inside a thermostatic water bath at $30{ }^{\circ} \mathrm{C}$ (Julabo, Model EH, Germany). The permeability was calculated using Equation (10):

$$
\frac{1}{\beta} \ln \left(\frac{\Delta p_{0}}{\Delta p}\right)=P \frac{t}{\delta}
$$


where $\Delta p$ (mbar) is the pressure difference between the feed and permeate compartment, $P\left(\mathrm{~mol} \cdot \mathrm{m} / \mathrm{m}^{2} \cdot \mathrm{s} \cdot \mathrm{Pa}\right)$ is the gas permeability, $t(\mathrm{~s})$ is the time, $\delta(\mathrm{m})$ is the film thickness and $\beta$ is the geometric parameter of the cell [35].

\subsection{Data Statistical Treatment}

All experiments were conducted using a completely randomized design with three replications.

A statistical analysis of data was performed through a one-way analysis of variance using OriginLab software version 8.5 , and differences among mean values were processed by the Tukey test. Significance was defined at $p<0.05$.

\section{Results and Discussion}

\subsection{X-ray Diffraction}

The diffractograms of pristine MMT and pure chitosan films or films incorporated with sodium montmorillonite and/or with ginger essential oil are shown in Figure 1. Montmorillonite exhibited a characteristic reflection peak at about $2 \theta=7.512^{\circ}$, corresponding to a basal spacing between the individual MMT layers of $\mathrm{d} 001=1.18 \mathrm{~nm}$. In the film incorporated only with MMT, the nanoclay characteristic reflection peak has disappeared, probably as the result of a disordered configuration of the lamellar structure not detectable by XRD, providing strong evidence that the clay nanolayers are exfoliated [36,37]. The incorporation of GEO resulted in the shift of the characteristic montmorillonite crystalline peak to smaller angles around $2 \theta=5.02^{\circ}\left(0.5 \%\right.$ GEO), $5.18^{\circ}\left(1 \%\right.$ GEO) and $5.22^{\circ}(2 \%$ GEO), corresponding to a basal spacing between the individual MMT layers of d001 $=1.76 ; 1.71$, and $1.69 \mathrm{~nm}$ respectively. Similar values ( $2 \theta$ between $5.04^{\circ}$ and $5.20^{\circ}$ ), were found for the interplanar distance in chitosan films incorporated with rosemary essential oil [16]. The increase of the distances between the lamellae of the clay is an indication that the chitosan was able to intercalate between the MMT layers, obtaining an intercalated structure [36,38]. However, ginger essential oil reduced chitosan dispersion in the MMT galleries, probably due to structural changes in the polymer due to the interactions of the phenolic compounds with the chitosan reactive groups [37].

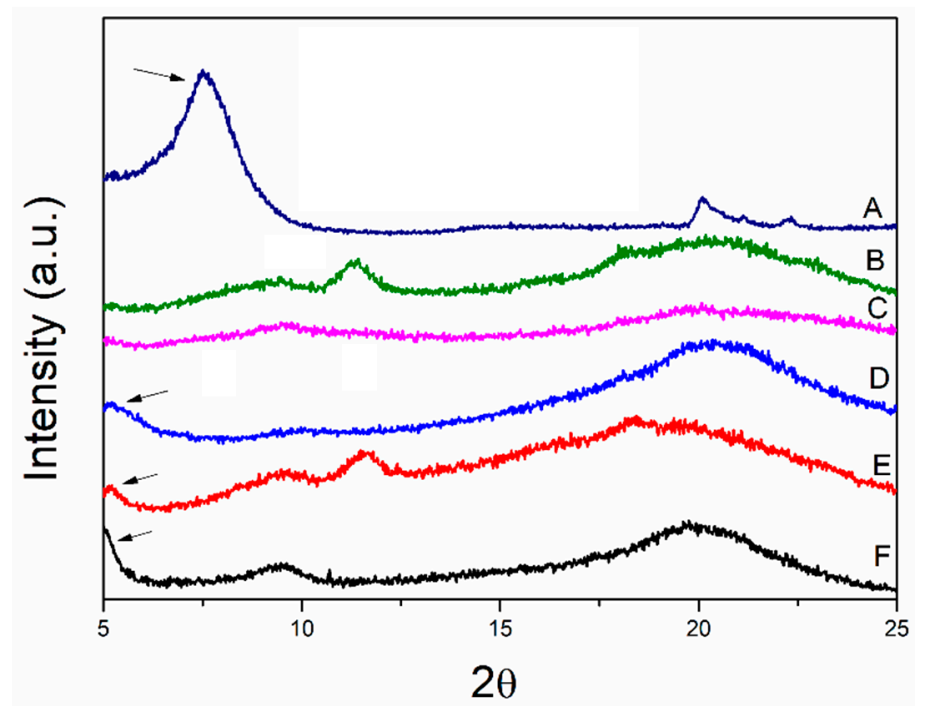

Figure 1. XRD of (A) pristine sodium montmorillonite (MMT), (B) chitosan film, (C) chitosan + MMT film, (D) chitosan + MMT + 2\% GEO film, (E) chitosan + MMT + 1\% GEO film, and (F) chitosan + MMT + 0.5\% GEO film. 


\subsection{Attenuated Total Reflectance Fourier Transform Infrared Spectroscopy (ATR-FTIR)}

Figure 2 depicts the FT-IR spectra of the bionanocomposites produced. Chitosan characteristic absorption bands were observed in all spectra, namely: at $3325 \mathrm{~cm}^{-1}$ (axial stretch of $-\mathrm{OH}$ ); at $3265-3277 \mathrm{~cm}^{-1}$ (asymmetric stretch of the $-\mathrm{NH}$ group); at $2877-2925 \mathrm{~cm}^{-1}$ (C-H bond of the methyl group $-\mathrm{NHCOCH}_{3}$ ); at 1638-1642 $\mathrm{cm}^{-1}$ (amide I); at 1551-1558 $\mathrm{cm}^{-1}$ (amide II); at $1342 \mathrm{~cm}^{-1}$ (skeletal vibration involving the stretching of the $\mathrm{C}-\mathrm{N}$ bond of amide III); at 1375-1412 $\mathrm{cm}^{-1}$ (-CH2 folding); at 906-1024 $\mathrm{cm}^{-1}$ (skeletal vibration involving the stretching of the $\mathrm{C}-\mathrm{O}$ group); and at $1134 \mathrm{~cm}^{-1}$ (asymmetric stretching of the C-O-C bridges) $[29,39,40]$. Overall, the incorporation of GEO or MMT did not result in great differences in the spectra when compared to pristine chitosan film, probably due to the small quantity incorporated, i.e., chitosan characteristic peaks have prevailed in all samples. However, small changes in the intensities of the absorption peaks were recorded, which are attributed to the overlap of chemical bonds, and thus an indication of the presence of strong interaction between the molecules of the different components of the material (chitosan, MMT, and the active compounds present in GEO) [41]. The spectra of the films incorporated with GEO show a new peak between $1702-1703 \mathrm{~cm}^{-1}$ which corresponds to the vibration of the $\mathrm{C}=\mathrm{O}$ bond stretch, the increase in this peak intensity with increasing oil concentration is an indication that there were interactions between the phenolic compounds present in the essential oil and the hydroxyl and amine groups of chitosan [42]. The appearance of this new peak as well as the displacement of peaks at different wavelengths (as observed between $860-880 \mathrm{~cm}^{-1}$ or 1250-1300 $\mathrm{cm}^{-1}$, for example) with the incorporation of GEO are indicative that new covalent bonds between the chitosan and active compounds from GEO or MMT occurred [43]. These results corroborate the observations obtained in the analyses of XRD and SEM as well as the modifications in the functional properties of the films produced.

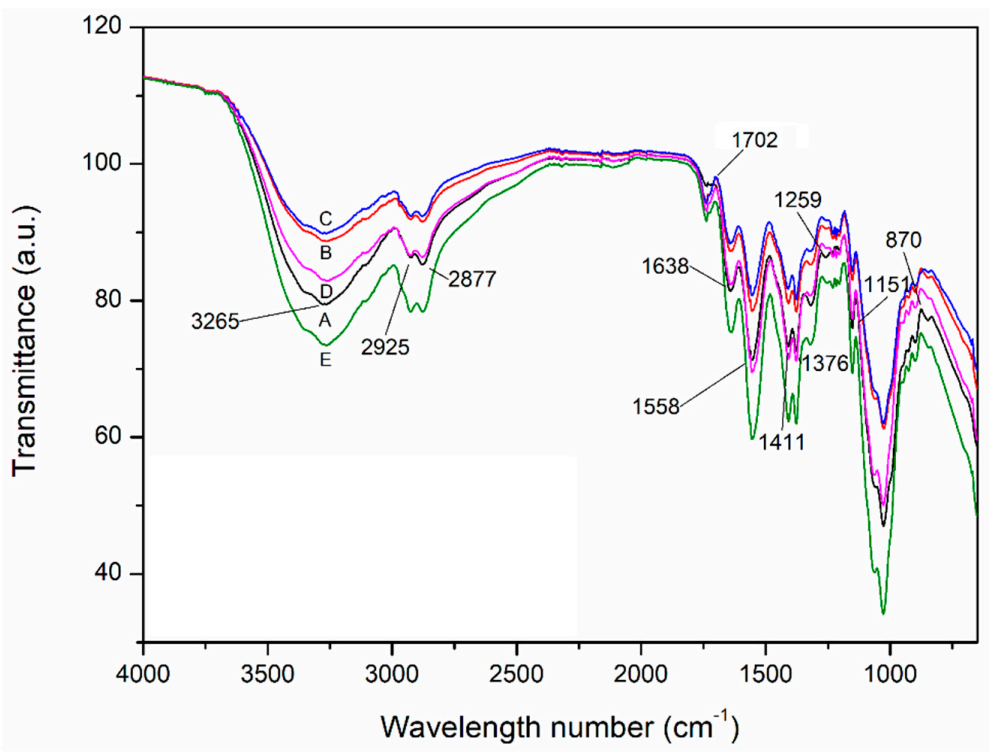

Figure 2. ATR-FTIR spectra of chitosan (Ch)-based films (A) incorporated with: (B) MMT; (C) MMT + $0.5 \%$ GEO; (D) MMT + 1\% GEO; and (E) MMT + 2\% GEO.

\subsection{Morphological Characterization}

Scanning electron microscopy images in Figure 3 correspond to the surface (Figure 3A,C,E,G) and cross-section (Figure 3B,D,F,G) of chitosan films and those containing MMT, $2 \%$ GEO, or $2 \%$ GEO + MMT.

The surface of the film showed high uniformity (Figure 3). However, the addition of GEO (2\%) caused a certain discontinuity in the topography of the films (Figure 3E), which was more evident when MMT was also incorporated (Figure 3G). This less homogeneous surface (greater irregularity/less smooth) may have been the result of the presence of droplets under the surface of the film (internal aggregates) that changed the topography of the film. 


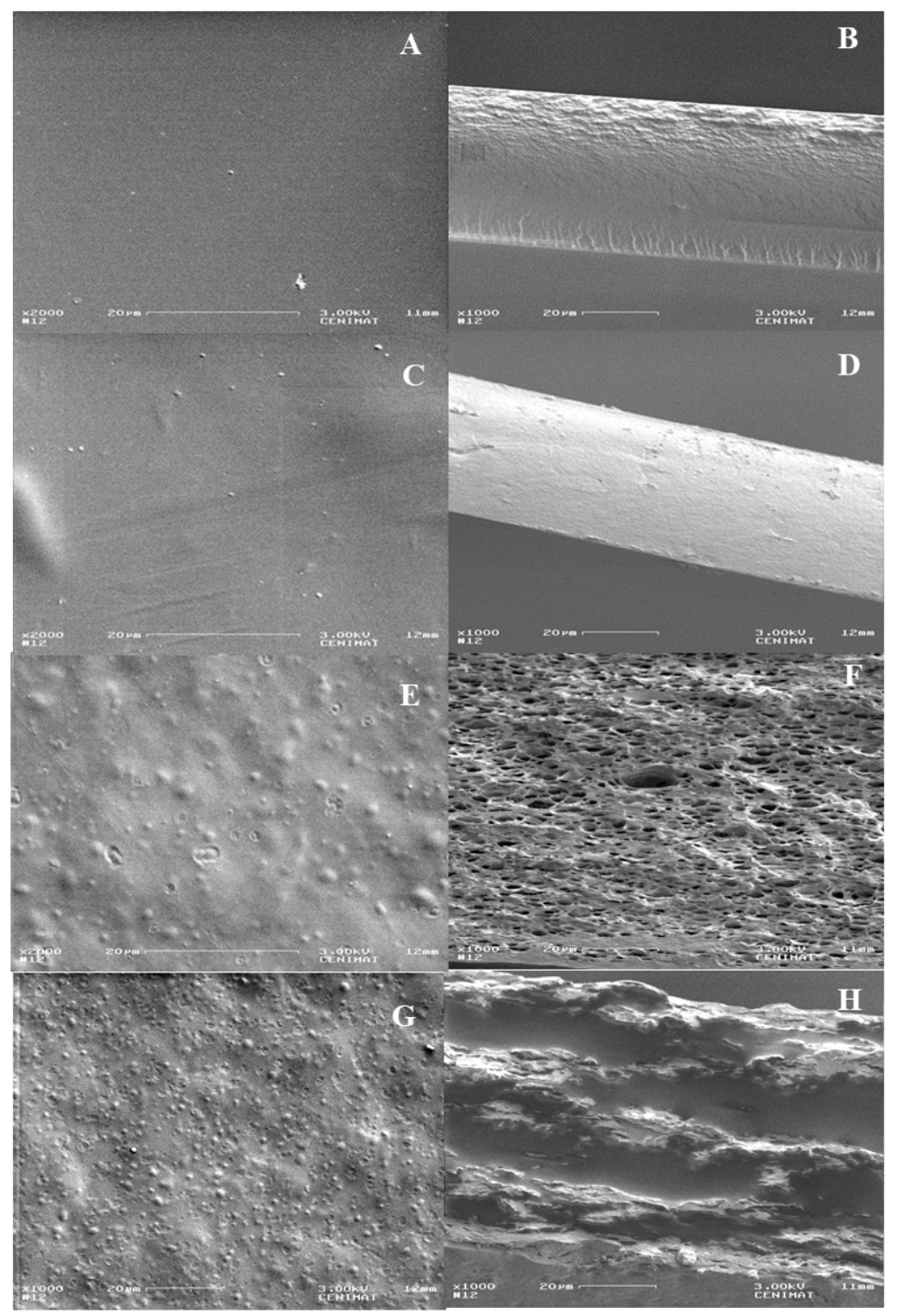

Figure 3. Scanning electron microscopy micrographs of surface and cross-section, respectively: chitosan film (A and B), chitosan film + MMT (C and D), chitosan film + 2\% GEO (E and F), and chitosan film + $\mathrm{MMT}+2 \%$ GEO (G and $\mathbf{H})$.

The cross-sections of the pristine chitosan film (Figure 3B) and chitosan + MMT (Figure 3D) show high homogeneity of the polymer structure was obtained. The incorporation of MMT seems to have contributed to make the network even more compact, being an indicative of achievement of high interaction between chitosan and the nanoclay, which corroborates the XRD results. The incorporation of $2 \%$ of GEO resulted in an internal structure with a "spongy like" pattern (Figure 3F), probably due to the presence of internal oil droplets that also increases the surface coarseness [44]. When both oil and MMT were incorporated (Figure $3 \mathrm{H}$ ), there was a complete change in the network structure (with an increase in the internal spacing), however with indications of greater interaction than in the film only incorporated with GEO.

Figure $3 \mathrm{~F}, \mathrm{H}$ shows the cross section of chitosan $+2 \%$ GEO and chitosan $+2 \%$ GEO + MMT, respectively; they are in the same amplification used for the images of pristine chitosan film (Figure 3B) and chitosan + MMT (Figure 3D); however, it is noticeable that the formers have wider cross sections (larger images). This observation is related to the increase in the thickness resulting from the incorporation of the essential oil, which corroborates the results discussed in Section 3.5. 


\subsection{Thermal Properties}

The glass transition temperatures as well as the mass losses with their respective maximum degradation temperatures were determined by the DSC and TGA assays, respectively.

The $\mathrm{Tg}$ of the films did not statistically change with the incorporation of MMT nor GEO $(p>0.05)$ (Table 1), with an average value of $199 \pm 14{ }^{\circ} \mathrm{C}$. However, there was a tendency for $\mathrm{Tg}$ to decrease with the incorporation of GEO and MMT, which is an indication of a greater relaxation of the polymer chains, probably due to the plasticizing effect of the essential oil [45]. Similar results were found for chitosan films incorporated with sodium montmorillonite and rosemary essential oil [16]. Moreover, this tendency also corroborates the mechanical results discussed in Section 3.5.

Thermogravimetric analysis is a technique where the mass of a substance is monitored as a function of temperature increase under controlled conditions of temperature and atmosphere (usually under an inert gas flow such as nitrogen) [46]. The thermal degradation temperatures (Td), mass losses (\% $\Delta \mathrm{M})$ and the sample residues (\%) are shown in Table 1.

Regarding the thermal degradation process, two different behaviors were observed, namely: for the films without incorporation of GEO, three thermal degradation events were registered, whereas for biopolymers incorporated with GEO, four stages were found. Similar behavior was observed in chitosan films incorporated with Satureja hortensis essential oil [14].

The first thermal event occurred in average temperatures between $59.6{ }^{\circ} \mathrm{C}$ and $70.9{ }^{\circ} \mathrm{C}$ with mass losses between $4.1 \%$ and $6.5 \%$. The mass loss in this first stage is related to the evaporation of the water and residual acetic acid present in the polymer matrix. The lower mass loss observed for the films incorporated with GEO was probably due to the lower water content resulting from the incorporation of the hydrophobic compounds present in the essential oil [47]. The second thermal degradation stage $\left(135.5^{\circ} \mathrm{C}-183.4{ }^{\circ} \mathrm{C}\right)$ corresponded to a loss of mass between $11.1 \%$ and $16.6 \%$ and is related to the decomposition of low molecular weight or structurally bonded components to water in the chitosan network [14].

The third, and largest mass loss $(19.9 \%-33 \%)$ occurred at temperatures between $283.5^{\circ} \mathrm{C}-290.8^{\circ} \mathrm{C}$ and is associated with the degradation of chitosan (the main component of the bionanocomposites), i.e., it is associated with the dehydration of the saccharide ring, depolymerization, and pyrolytic decomposition of acetylated or deacetylated chitosan units [14,36]. The incorporation of GEO slightly increased the thermal stability of the film since the maximum degradation temperature at this stage was higher in films incorporated with the essential oil. These results are in good agreement with those observed in chitosan-carboxymethyl cellulose films which were also incorporated with ginger essential oil [48]. Those authors attributed the increase in thermal stability to the increase in the organization of the polymer matrix (i.e., to a more homogeneous structure) with the incorporation of GEO, which resulted in higher temperatures of thermal degradation [48].

The fourth and final stage of degradation occurred between $397.1^{\circ} \mathrm{C}$ and $409.5^{\circ} \mathrm{C}$, and only for the films incorporated with GEO. This stage is related to the degradation of the thermally stable compounds present in the GEO, as also observed by Alizadeh et al. (2018) [14].

The incorporation of MMT acted as a thermal barrier, providing lower mass losses, as can be observed in the final residue of the thermal process. The increase in thermal stability induced by the addition of clays to polymer composites is commonly observed and is related to the level of dispersion and the aspect ratio obtained [13]. Exfoliation/intercalation of the clay layers between the polymer matrix increases the tortuosity of the combustion gases diffusion pathway, favoring the formation of a protection on the surface of the material (thermal insulation), contributing to the increase in degradation temperatures [11,13]. This finding is in agreement with a previous study [49].

The thermal decomposition residues of biopolymers at the end of the heating cycle (up to $900{ }^{\circ} \mathrm{C}$ ) incorporated with GEO were lower compared to the control, whereas the composites with MMT increased the amount of ash. Similar behaviors were reported in the literature-Alizadeh et al. (2018) [14] observed the decrease of mineral residue with the incorporation of essential oil in chitosan films, whereas Rimdusit et al. (2008) [50] reported a slight increase in the amount of ash in the methylcellulose biopolymers incorporated with montmorillonite and attributed this increase to the inorganic clay characteristic. 
Table 1. Summary of the thermal analyses results of active bionanocomposites.

\begin{tabular}{|c|c|c|c|c|c|c|c|c|c|c|}
\hline \multirow{2}{*}{ Film } & \multirow{2}{*}{$\operatorname{Tg}\left({ }^{\circ} \mathrm{C}\right)$} & \multicolumn{2}{|c|}{$\Delta \mathbf{1}$} & \multicolumn{2}{|c|}{$\Delta 2$} & \multicolumn{2}{|c|}{$\Delta 3$} & \multicolumn{2}{|c|}{$\Delta 4$} & \multirow{2}{*}{ Residue $(\%)$} \\
\hline & & $\operatorname{Td}\left({ }^{\circ} \mathrm{C}\right)$ & $\Delta \mathrm{M}(\%)$ & $\operatorname{Td}\left({ }^{\circ} \mathrm{C}\right)$ & $\Delta \mathrm{M}(\%)$ & $\operatorname{Td}\left({ }^{\circ} \mathrm{C}\right)$ & $\Delta \mathrm{M}(\%)$ & $\operatorname{Td}\left({ }^{\circ} \mathrm{C}\right)$ & $\Delta \mathrm{M}(\%)$ & \\
\hline $\mathrm{Ch}$ & $206.7 \pm 3.7^{\mathrm{ns} * *}$ & $70.9 \pm 2.5$ & $6.5 \pm 0.0$ & $170.1 \pm 1.5$ & $12.6 \pm 0.8$ & $283.6 \pm 0.7$ & $24.3 \pm 0.6$ & - & - & $23.6 \pm 0.4$ \\
\hline $\mathrm{Ch}+\mathrm{MMT}$ & $188.9 \pm 6.7^{\mathrm{ns}}$ & $63.6 \pm 2.4$ & $6.4 \pm 0.8$ & $173.2 \pm 0.8$ & $14.0 \pm 0.8$ & $283.5 \pm 0.5$ & $23.2 \pm 0.2$ & - & - & $25.8 \pm 0.1$ \\
\hline $\mathrm{Ch}+0.5 \% \mathrm{GEO}$ & $202.2 \pm 2.7^{\mathrm{ns}}$ & $65.6 \pm 2.4$ & $6.1 \pm 0.2$ & $174.1 \pm 2.1$ & $13.7 \pm 0.1$ & $284.0 \pm 1.0$ & $20.4 \pm 0.4$ & $407.4 \pm 5.6$ & $26.6 \pm 0.6$ & $18.0 \pm 0.1$ \\
\hline $\mathrm{Ch}+\mathrm{MMT}+0.5 \%$ GEO & $202.8 \pm 5.4^{\mathrm{ns}}$ & $64.0 \pm 0.0$ & $6.2 \pm 0.3$ & $168.4 \pm 3.2$ & $11.5 \pm 0.6$ & $284.0 \pm 0.9$ & $20.4 \pm 0.0$ & $407.8 \pm 0.4$ & $26.9 \pm 0.4$ & $20.2 \pm 0.4$ \\
\hline $\mathrm{Ch}+1 \% \mathrm{GEO}$ & $194.4 \pm 7.1^{\mathrm{ns}}$ & $63.2 \pm 1.5$ & $4.9 \pm 0.2$ & $167.4 \pm 1.3$ & $11.1 \pm 2.7$ & $284.1 \pm 2.5$ & $19.9 \pm 1.7$ & $397.1 \pm 6.2$ & $27.1 \pm 5.7$ & $16.9 \pm 0.8$ \\
\hline $\mathrm{Ch}+\mathrm{MMT}+1 \% \mathrm{GEO}$ & $196.2 \pm 3.4^{\mathrm{ns}}$ & $64.8 \pm 1.9$ & $4.7 \pm 0.1$ & $172.6 \pm 3.7$ & $16.1 \pm 0.3$ & $290.8 \pm 1.1$ & $25.2 \pm 0.4$ & $409.5 \pm 2.6$ & $26.9 \pm 0.8$ & $17.7 \pm 0.3$ \\
\hline $\mathrm{Ch}+2 \% \mathrm{GEO}$ & $195.5 \pm 4.8^{\mathrm{ns}}$ & $59.6 \pm 6.3$ & $4.1 \pm 0.2$ & $135.5 \pm 3.2$ & $13.1 \pm 1.3$ & $284.8 \pm 0.7$ & $33.0 \pm 0.5$ & $407.1 \pm 3.2$ & $25.0 \pm 0.6$ & $14.2 \pm 1.0$ \\
\hline $\mathrm{Ch}+\mathrm{MMT}+2 \% \mathrm{GEO}$ & $194.3 \pm 6.8^{\mathrm{ns}}$ & $63.7 \pm 0.9$ & $5.0 \pm 0.2$ & $183.4 \pm 2.5$ & $16.6 \pm 0.6$ & $287.7 \pm 0.5$ & $23.2 \pm 0.9$ & $408.7 \pm 3.1$ & $25.9 \pm 0.6$ & $18.0 \pm 0.4$ \\
\hline
\end{tabular}

Chitosan (Ch); sodium montmorillonite (MMT); ginger essential oil (GEO); glass transition temperature (Tg); decomposition temperature (Td); mass loss ( $\Delta \mathrm{M}){ }^{* *} \mathrm{~ns}$ : non-significance statistical difference $(p>0.05)$. 


\subsection{Thickness and Mechanical Properties}

The incorporation of MMT did not statistically change the film thickness $(p>0.05$; Table 2). However, in general, the thickness of the films incorporated with MMT were slightly lower than those found for the films without nanoreinforcement, and in some cases this difference was statistically significant (chitosan $+\mathrm{MMT}+0.5 \%$ GEO or $2 \%$ GEO) $(p<0.05)$. As verified in the XRD assay, the films incorporated with MMT and GEO showed evidence of obtaining an intercalated (partially exfoliated) configuration, characterized by the formation of strong bonds between the polymer and the clay due to penetration of the chitosan chains [51], allowing the formation of a compact structure which minimized the increase in thickness due to the incorporation of GEO.

On the other hand, the incorporation of GEO resulted in a significant increase in the film thickness; moreover, a concentration effect was also observed, i.e., the greater the GEO content incorporated, the greater the thickness of the samples ( $p<0.05$; Table 2$)$. This behavior can be explained by the higher content of solids per unit area [52], or due to the interactions between the chitosan and the active compounds present in the bioactive extracts that may have reduced the alignment of the polymer chains, reducing the compression of the formed network [47] and consequently increasing the thickness of the films.

Peng and Li (2014) [53] observed an increase in the thickness of chitosan films due to the incorporation of $1 \%$ of three different essential oils. Pure chitosan film had an average thickness of $77 \mu \mathrm{m}$ whereas in treatments incorporated with citronella, thyme, or cinnamon essential oils, the recorded thicknesses were 97,101 , and $99 \mu \mathrm{m}$, respectively. That is, an increase of about $30 \%$ compared to the control. In our results, for the same essential oil content, the films showed an increase in thickness of about $62 \%$. In another study, also with chitosan films incorporated with a mixture of ginger and cinnamon essential oils (1:1) in different concentrations $(0.05 \%, 0.2 \%$, or $1 \%)$, the thickness of the films produced varied significantly due to the addition of EOs (between 68 and $105 \mu \mathrm{m}$ ) [54]. This variation represents a $54 \%$ increase in the thickness with the addition of $1 \%$ of the mixture of the oils used, which is a result close to the $62 \%$ found in the present work.

The most common parameters that describe the mechanical properties of edible films are the maximum tensile strength at break (TS), the elongation at break (\%EAB) and the elastic or Young's modulus (EM), which are strongly related to the chemical structure of the material. The TS indicates the film strength, \%EAB corresponds to the material's deformation capacity, while EM evaluates the film rigidity $[44,55]$. Improved mechanical properties, structural integrity, and better flexibility are expected in polymer-based composite materials [56].

The results of the mechanical parameters evaluated (TS, \%EAB and EM) are shown in Table 2. In the films where the natural extract was not incorporated (chitosan and chitosan + MMT) the nanoclay increased the tensile strength of the biopolymers as well as their plasticity $(p<0.05)$, without, however, interfering with the stiffness of the samples $(p>0.05$; Table 2). This can be attributed to the uniform dispersion of MMT in the chitosan matrix (i.e., achievement of an exfoliated or intercalated conformation) and the strong interaction between the polymer and montmorillonite, as previously discussed.

The incorporation of ginger essential oil resulted in films that were less resistant to traction, more elastic, and less rigid. Regarding TS, there was a reduction between $0.6 \%$ and $31.6 \%$ (for films containing between $0.5 \%$ and $2 \%$ GEO; Table 2). The incorporation of MMT did not result in difference in the TS of the films also incorporated with GEO $(p>0.05)$. The incorporation of lipids into the polymeric matrix of films induces the formation of heterogeneous and discontinuous structures, which affect the mechanical resistance of the polymers by the partial replacement of the strong polar chemical bonds chitosan-chitosan (between the chitosan molecules) by weaker interactions between chitosan-GEO (active molecules present in GEO) [23]. 
Table 2. Summary of thickness, mechanical properties, contact angle, water solubility and swelling degree of active bionanocomposites.

\begin{tabular}{|c|c|c|c|c|c|c|c|c|}
\hline \multirow{2}{*}{ GEO (\%) } & \multicolumn{2}{|c|}{ Thickness $(\mu \mathrm{m})$} & \multicolumn{2}{|c|}{ Tensile Strength (MPa) } & \multicolumn{2}{|c|}{ EAB (\%) } & \multicolumn{2}{|c|}{ Elastic Modulus (GPa) } \\
\hline & 0\% MMT & $2.5 \% \mathrm{MMT}$ & 0\% MMT & $2.5 \%$ MMT & 0\% MMT & $2.5 \%$ MMT & 0\% MMT & $2.5 \%$ MMT \\
\hline 0 & $41.7 \pm 2.9 \mathrm{Da} *$ & $39.5 \pm 2.0 \mathrm{Ca}$ & $46.7 \pm 1.7 \mathrm{Ab}$ & $66.6 \pm 3.1 \mathrm{Aa}$ & $17.9 \pm 1.2^{\mathrm{Bb}}$ & $33.5 \pm 2.5 \mathrm{Aa}$ & $2.05 \pm 0.19 \mathrm{Aa}$ & $1.86 \pm 0.14 \mathrm{Aa}$ \\
\hline 0.5 & $55.5 \pm 1.3 \mathrm{Ca}$ & $52.5 \pm 0.6^{\mathrm{Bb}}$ & $46.3 \pm 5.1 \mathrm{Aa}$ & $42.0 \pm 4.2^{\mathrm{Ba}}$ & $23.8 \pm 5.3 \mathrm{ABa}$ & $22.3 \pm 2.9 \mathrm{Ba}$ & $1.66 \pm .012 \mathrm{Aa}$ & $1.30 \pm 0.30 \mathrm{Ba}$ \\
\hline 1.0 & $68.2 \pm 3.1 \mathrm{Ba}$ & $67.4 \pm 1.1 \mathrm{Aa}$ & $27.2 \pm 5.8 \mathrm{Ba}$ & $34.6 \pm 1.0 \mathrm{BCa}$ & $36.0 \pm 9.4 \mathrm{Aa}$ & $33.1 \pm 2.3 \mathrm{Aa}$ & $0.30 \pm 0.09 \mathrm{Cb}$ & $0.88 \pm 0.13^{\mathrm{BCa}}$ \\
\hline 2.0 & $81.3 \pm 4.5^{\mathrm{Aa}}$ & $68.6 \pm 0.9^{\mathrm{Ab}}$ & $32.1 \pm 3.9 \mathrm{Ba}$ & $30.3 \pm 0.7 \mathrm{Ca}$ & $33.6 \pm 6.6^{\mathrm{ABa}}$ & $35.8 \pm 1.3^{\mathrm{Aa}}$ & $0.71 \pm 0.15^{\mathrm{Ba}}$ & $0.47 \pm 0.05 \mathrm{Ca}$ \\
\hline \multirow{2}{*}{ GEO (\%) } & \multicolumn{2}{|c|}{ Water Solubility (\%) } & \multicolumn{2}{|c|}{ Swelling Degree (\%) } & \multicolumn{2}{|c|}{ Contact Angle (Degrees) } & & \\
\hline & 0\% MMT & $2.5 \%$ MMT & 0\% MMT & $2.5 \%$ MMT & 0\% MMT & $2.5 \%$ MMT & & \\
\hline 0 & $23.1 \pm 1.6^{\mathrm{Aa}}$ & $20.4 \pm 0.6^{\mathrm{Bb}}$ & $132.3 \pm 10.0 \mathrm{Ab} *$ & $192.2 \pm 13.3^{\text {Аа }}$ & $70.9 \pm 4.0 \mathrm{Ab}$ & $90.6 \pm 5.5^{\mathrm{Aa}}$ & & \\
\hline 0.5 & $20.3 \pm 0.4 \mathrm{Ab}$ & $21.9 \pm 0.6^{\mathrm{Ba}}$ & $124.6 \pm 3.5$ Аа & $35.1 \pm 20.7 \mathrm{Cb}$ & $70.3 \pm 7.5 \mathrm{Aa}$ & $68.6 \pm 1.6^{\mathrm{Ba}}$ & & \\
\hline 1.0 & $16.4 \pm 0.4^{\mathrm{Bb}}$ & $18.7 \pm 0.2^{\mathrm{Ba}}$ & $97.8 \pm 18.2^{\mathrm{Ba}}$ & $97.0 \pm 13.4 \mathrm{Ba}$ & $66.6 \pm 5.5^{\mathrm{Aa}}$ & $70.9 \pm 3.2 \mathrm{Ba}$ & & \\
\hline 2.0 & $19.6 \pm 2.1 \mathrm{ABa}$ & $23.5 \pm 2.4 \mathrm{Aa}$ & $87.0 \pm 2.5^{\mathrm{Ba}}$ & $54.7 \pm 20.5^{\text {ВСа }}$ & $57.2 \pm 1.9 \mathrm{Ba}$ & $63.8 \pm 7.6^{\mathrm{Ba}}$ & & \\
\hline
\end{tabular}

(A-D): Within each parameter, values in the same column not sharing upper case superscript letters indicate statistically significant differences among formulations $(p<0.05)$. (a-b): Within each parameter, values in the same line not sharing lower case superscript letters indicate statistically significant differences among formulations ( $p<0.05)$. Ginger Essential Oil (GEO); Sodium Montmorillonite (MMT); Elongation at break (EAB). 
Several authors reported a reduction in TS of different biopolymers due to the incorporation of essential oils into their structure (ginger and cinnamon EOs in sodium caseinate films [57]; oregano EO in triticale protein films [58]; thyme, rosemary, and oregano EOs in polylactic acid (PLA) films [59], or essential oils extracted from roots (gingers and saffron) incorporated into gelatin films extracted from fish skin [47]). This behavior was also observed, however with less intensity in chitosan films incorporated with REO [16], probably due to the different chemical compositions of the oils [23].

Regarding the elongation at break, the incorporation of GEO resulted in films with increased extensibility $(p<0.05)$, probably due to the discontinuity of the polymer matrix due to the weaker interactions between chitosan molecules and essential oil components, such as discussed above. The incorporation of MMT, again, did not result in changes in this property $(p>0.05)$, as the \%EAB of the films with the same concentrations of GEO, incorporated with MMT or not, did not differ from each other (Table 2).

Therefore, the ginger essential oil probably acted as a plasticizer, as it decreased the strength of the films while increasing their plasticity (ability to stretch before tearing/breaking). In addition, this plasticizing effect of EOs in biopolymers is influenced by the contents of the extracts incorporated in the polymer matrix [47]; as observed in the results (Table 2), greater changes in the mechanical properties were observed with the higher GEO concentrations incorporated.

Materials with lower tensile strength and higher plasticity (\%EAB) are also less rigid, which was also observed for chitosan films with the incorporation of GEO (statistically reduced the elastic modulus, $p<0.05$; Table 2). Similar behavior was also observed in chitosan films incorporated with cinnamon essential oil [52] or in PLA films incorporated with different types of essential oils [59].

According to Zeid et. al. (2019) [59], it is difficult to compare results with different types of materials and additives under different processing conditions; thus, it is crucial to have more available data regarding these novel materials. Furthermore, the application of other techniques to study the rheology of the film form dispersion may contribute with valuable information for understanding the materials' behavior, as it will influence their final specific application [56].

\subsection{Optical Properties}

It is important to study the optical properties of food contact material because these may interfere on consumer acceptance of the food packaged, as the film can affect the general appearance of the product inside the packaging [53].

Optical properties are shown in Table 3. The incorporation of GEO or MMT decreased the hue value (i.e., films with a more yellow color) while increasing film opacity and color saturation (i.e., greater chromaticity, $p<0.05$ ). Similar results were observed in bionanocomposites of chitosan/montmorillonite incorporated with REO [16], as well as those reported for chitosan films incorporated with cinnamon EO [52], citronella, or thyme EOs [53].

The chemical bonding of different molecules to the polymer chain also modifies the properties of the material in terms of light absorption [60], as observed in chitosan films incorporated with natural extracts rich in phenolic compounds [61]. According to Acevedo-Fani et al. (2015) [44], the oil droplets present internally in the polymer matrix can increase the light scattering at the interface of the droplets, resulting in an increase in the opacity values of the material.

Figure 4 depicts the scanning spectra of the percentage of light transmitted through the film between wavelengths of 190-900 nm. Both the incorporation of GEO and MMT reduced the transparency of the films. A high barrier to UV light (wavelengths less than $350 \mathrm{~nm}$ ) is desirable in food packaging materials since these can be applied to the preservation of oxidative processes [17]. However, in the wavelengths of visible light, the greater the opacity of the material, the worse is its acceptance by the consumer (who always looks for transparent films capable of exposing the packaged product) [53]. Thus, the bionanocomposites produced have this disadvantage from the visual point of view, despite the positive aspect of greater protection of the packaged food (against light, as a secondary antioxidant material). 
Table 3. Summary of barrier and optical properties of the active bionanocomposite.

\begin{tabular}{|c|c|c|c|c|c|}
\hline Film & $\begin{array}{l}\text { WVP }\left(10^{-11}\right. \\
\mathrm{mol} / \mathrm{m} \cdot \mathrm{s} \cdot \mathrm{Pa})\end{array}$ & $\begin{array}{c}\mathrm{OP}\left(10^{-16}\right. \\
\mathrm{mol} / \mathrm{m} \cdot \mathrm{s} \cdot \mathrm{Pa})\end{array}$ & Cromaticity & Hue * & Opacity \\
\hline Ch & $1.40 \pm 0.09^{C *}$ & $0.184 \pm 0.052 \mathrm{DE}$ & $3.1 \pm 0.1^{\mathrm{D}}$ & $129.0 \pm 1.0^{\mathrm{A}}$ & $1.1 \pm 0.2^{C}$ \\
\hline $\mathrm{Ch}+\mathrm{MMT}$ & $1.75 \pm 0.10^{\mathrm{BC}}$ & $0.098 \pm 0.008^{\mathrm{F}}$ & $4.2 \pm 0.4^{\mathrm{C}}$ & $118.8 \pm 1.8^{\mathrm{B}}$ & $1.7 \pm 0.3^{C}$ \\
\hline $\mathrm{Ch}+0.5 \% \mathrm{GEO}$ & $1.93 \pm 0.36 \mathrm{ABC}$ & $0.182 \pm 0.008^{\mathrm{DE}}$ & $5.8 \pm 0.3^{B}$ & $112.3 \pm 0.6^{\mathrm{C}}$ & $2.6 \pm 0.1^{\mathrm{B}}$ \\
\hline $\mathrm{Ch}+\mathrm{MMT}+0.5 \% \mathrm{GEO}$ & $1.94 \pm 0.27 \mathrm{ABC}$ & $0.171 \pm 0.001^{\mathrm{E}}$ & $6.8 \pm 0.6^{\mathrm{B}}$ & $109.8 \pm 1.4^{\mathrm{CD}}$ & $3.1 \pm 0.7^{\mathrm{B}}$ \\
\hline $\mathrm{Ch}+1 \% \mathrm{GEO}$ & $1.95 \pm 0.21 \mathrm{ABC}$ & $0.255 \pm 0.010^{\mathrm{BC}}$ & $7.0 \pm 0.8^{\mathrm{B}}$ & $110.2 \pm 1.3^{C D}$ & $4.1 \pm 0.1 \mathrm{AB}$ \\
\hline $\mathrm{Ch}+\mathrm{MMT}+1 \% \mathrm{GEO}$ & $2.12 \pm 0.08 \mathrm{AB}$ & $0.246 \pm 0.013 \mathrm{CD}$ & $8.0 \pm 0.2 \mathrm{AB}$ & $107.9 \pm 0.1 \mathrm{DE}$ & $5.0 \pm 0.2 \mathrm{AB}$ \\
\hline $\mathrm{Ch}+2 \% \mathrm{GEO}$ & $1.94 \pm 0.10 \mathrm{ABC}$ & $0.325 \pm 0.037^{\mathrm{A}}$ & $9.6 \pm 1.9^{\mathrm{A}}$ & $107.1 \pm 1.8^{\mathrm{DE}}$ & $4.2 \pm 1.4 \mathrm{AB}$ \\
\hline $\mathrm{Ch}+\mathrm{MMT}+2 \% \mathrm{GEO}$ & $2.41 \pm 0.16^{\mathrm{A}}$ & $0.285 \pm 0.015 \mathrm{AB}$ & $9.7 \pm 1.3^{\mathrm{A}}$ & $105.1 \pm 0.7^{\mathrm{E}}$ & $6.2 \pm 1.8^{\mathrm{A}}$ \\
\hline
\end{tabular}

(A-E): values in the same column not sharing upper case superscript letters indicate statistically significant differences among formulations $(p<0.05)$. Chitosan $(\mathrm{Ch})$; ginger essential oil $(\mathrm{OEG})$; sodium montmorillonite (MMT); oxygen permeability (OP); water vapor permeability (WVP).
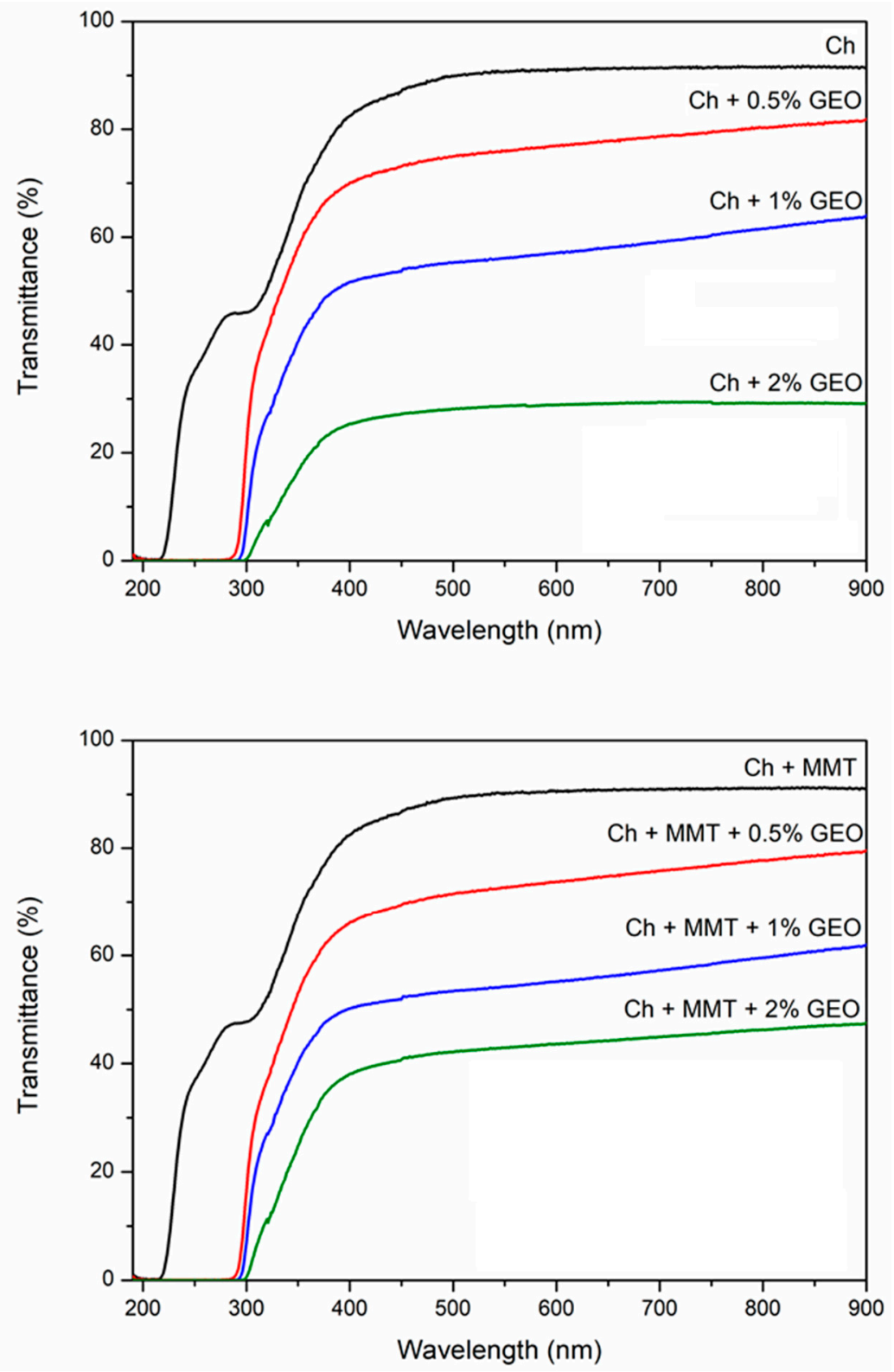

Figure 4. Film transparency of biopolymers produced. Ch, chitosan; MMT, sodium montmorillonite; GEO, ginger essential oil. 


\subsection{Solubility in Water, Swelling Degree and Contact Angle}

The study of the film's solubility in water, contact angle, and swelling degree with water plays an important role when developing novel materials for food applications, as it provides insights on material behavior in contact with aqueous food matrices and understanding of its resistance under this conditions [16,62].

The water solubility of bionanocomposites was affected by both factors evaluated (the incorporation of GEO and MMT; Table 2). Without the incorporation of MMT, only the films added with $1 \%$ of GEO presented lower values of solubility in water $(p<0.05)$ in comparison with the control film, probably due to phenolic compounds (present in GEO) cross-linking in the chitosan chain $[27,63]$ that reduced the release of polymer toward the water. Similar results were reported in the literature for biopolymers incorporated with natural compounds [51,64]. When GEO and MMT were incorporated into the films, only for samples with higher GEO content showed a significant increase in this parameter $(p<0.05)$. In general, MMT when associated with GEO contributed to an increase in the water solubility of the films, whereas in the films with GEO but without addition of the nanoclay, a tendency was observed for the decrease in this parameter.

Regarding the films' ability to absorb water, the incorporation of GEO resulted in a decrease in the swelling index $(p<0.05)$. The addition of montmorillonite enhanced even more the effect of diminishing the films' water-absorbing capacity. The formation of crosslinks between the active compounds of GEO and chitosan, as well as the good interaction of sodium montmorillonite with chitosan (due to the intercalated conformation achieved) and GEO, are responsible for the decrease in the ability of the films to absorb water. The chemical interactions created in the polymer matrix block the reactive groups of the chitosan from reacting with the water, thus diminishing its capacity to absorb it $[27,36,39,64]$.

Analyzing the contact angle of the films without the nanofiller, a tendency to increase film surface hydrophilicity (reduction of CA) with the incorporation of GEO was observed; however this difference was only statistically significant for the films with the highest concentration of GEO $(2 \%, p<0.05$; Table 2). For the films incorporated with both GEO and MMT, a decrease in the contact angle was also observed; however, in this case, the differences were statistically significant when compared to chitosan + MMT $(p<0.05)$, but not within different levels of GEO $(p>0.05)$. These results indicate the presence of hydrophilic substances on the surface of the films, probably phenolic compounds of GEO that enhanced the interaction with the water droplets [65].

\subsection{Barrier Properties}

It is desirable that packaging materials exhibit good barrier properties (against light, gases, or water vapor) in order to perform their function as outer physical protection against the external environment, enabling the shelf life extension of the food products packaged $[3,66]$.

Chitosan, a cationic polysaccharide, is a polymer with strong interactions in the polymer chain, which often restrict/decrease its movement, resulting in good oxygen barriers [67]. However, hydrogen bonds with water are also likely to happen, and water absorption occurs (water absorption breaks the intermolecular interactions between the polymer chains), so under conditions of high relative humidity the transmission rates increase, and consequently the permeability as well [68].

The film's water vapor permeability did not vary with the incorporation of MMT or GEO $(p>0.05)$, except for the film chitosan $+2 \%$ GEO + MMT that presented a lower barrier to water vapor when compared to chitosan or chitosan + MMT films $(p<0.05)$; however, this difference was not significant in relation to the other films also incorporated with GEO or GEO + MMT ( $p>0.05$; Table 3). Similar results were reported in a recent study with PLA incorporated with different essential oils at $10 \%(w / w)$ [59], the authors used thyme, rosemary, or oregano EOs to add antioxidant properties to the bio-based films and did not found statistical differences in the composites' WPV.

Despite the non-statistical differences in the WPV, a tendency of increase in permeability by the incorporation of both GEO and MMT was observed (Table 3). However, the effect of the GEO concentration 
on this change was not observed when MMT was not incorporated (WPV of films without MMT but with different levels of GEO were practically the same, around $1.94 \times 10^{-11} \mathrm{~mol} / \mathrm{m} \cdot \mathrm{s} \cdot \mathrm{Pa}$ ).

Contrary to what was observed, the incorporation of hydrophobic substances (such as oils) in the films should reduce the WPV, since the water vapor transfer process depends on the ratio between hydrophilic/hydrophobic constituents [69]. However, similar results were found by Atarés et al. (2011) [68], who observed an increase in WPV of hydroxymethyl cellulose films incorporated with GEO when the tests were performed at $35^{\circ} \mathrm{C}$, a similar temperature to the one used in our assay. According to these authors, the physical state in which the essential oil is found is a determinant in the effects caused in the WPV. For low temperatures, a decrease in permeability occurs, whereas for higher temperatures, when the oil is in the liquid state, it can favor the molecular mobility of the polymer chain, promoting the transport of molecules through the emulsified film [68]. Perdones et al. (2014) [52] attributed the increase in WPV of chitosan films incorporated with cinnamon essential oil to the possible interactions between the $\mathrm{EO}$ and chitosan components that made the polymer matrix more open to the transport of water molecules, and, at the same time, they plasticize the film. These results corroborate with the present WPV observed for the bionacomposites produced.

Regarding oxygen permeability, the incorporation of GEO reduced this gas barrier (Table 3). Similar results were observed when rosemary essential oil was incorporated in chitosan/montmorillonite composites [16]. It is possible that GEO acted as a plasticizer to the chitosan films, as it increased the elongation capacity of the material (\%EAB, as previously discussed), thus increasing both the permeability to oxygen and to water vapor. The plasticizers act as an internal lubricant, reducing the frictional forces between the polymer chains, and increasing the intermolecular space, thus allowing a greater mobility of the polymer chains and consequently facilitating the transport of gases [52,70].

A similar behavior was observed in chitosan films incorporated with cinnamon essential oil [52], and in films of hydroxypropylmethyl cellulose incorporated with GEO [68]. The liquid state of the essential oils as well as their hydrophobic character facilitate the transport of the oxygen through the film due to the increase of its solubility in the polymer matrix [68]. Montmorillonite helped to reduce the negative effect of incorporating GEO into the oxygen barrier. However, compared with commercial EVOH film, which is considered to be one of the best oxygen barrier packages, films incorporated with GEO exhibit OP in the same order of magnitude as EVOH $\left(0.24 \times 10^{-16} \mathrm{~mol} / \mathrm{m} \cdot \mathrm{s} \cdot \mathrm{Pa}\right)$ [71], demonstrating the potential of these films to protect against exposure to oxygen, and consequently to oxidative processes catalyzed by this gas. These results are in line with the results obtained from fresh poultry in an in situ study [28], in which samples wrapped with these bionanocomposites maintained their color and $\mathrm{pH}$ values and the thiobarbituric acid reactive substance index (TBARS) increased at a lower rate, helping to extend poultry meat shelf-life.

\section{Conclusions}

Homogeneous, transparent, yellowish, thin bionanocomposite films were successfully produced by casting. Furthermore, the homogenization process used to produce the films has proven to be adequate in achieving a good exfoliation of the MMT into the polymer chains. The good interaction between the composite's components (chitosan, MMT, and GEO constitutes) was demonstrated by the microscopy images, XRD, and FTIR results. The incorporation of GEO resulted in some irregularities on the film surface and changed the internal structure into a more "sponge like" shape. Overall, the incorporation of GEO resulted in films less resistant and more plastic, with lower barrier properties. However, the incorporation of MMT counterbalanced this effect. Thus, this work also shows that the incorporation of EOs into food packaging polymeric matrices is an interesting approach, as it reduces the EO amount necessary for preserving the foodstuff, therefore reducing costs and overcoming the aroma problem generally related to the directly incorporation of EOs into food. These novel bionanocomposites, therefore, have potential to be used as active packaging to preserve food products, but their application should also take into consideration their physical properties. 
Author Contributions: Conceptualization, V.G.L.S., M.P.D., I.M.C. and A.L.F.; Data curation, V.G.L.S.; Formal analysis, V.G.L.S., J.R.A.P., C.R., P.F.R., A.L., R.J.S. and J.C.; Investigation, V.G.L.S.; Methodology, V.G.L.S., J.R.A.P., C.R., P.F.R., A.L., R.J.S., J.C., M.P.D., I.M.C. and A.L.F.; Supervision, M.P.D., F.B.F., I.M.C. and A.L.F.; Writing-original draft, V.G.L.S., J.R.A.P., C.R., P.F.R., A.L., R.J.S., J.C., M.P.D., F.B.F., I.M.C. and A.L.F.; Writing-review and editing, M.P.D., F.B.F., I.M.C. and A.L.F.

Funding: This work was supported by CNPq - Brazil (grant number 200790/2014-5) and the MEtRICs unit which is financed by national funds from FCT/MCTES (UID/EMS/04077/2019). This work was also supported by the Associate Laboratory for Green Chemistry- LAQV which is financed by national funds from FCT/MCTES (UID/QUI/50006/2019) and UCIBIO, which is funded by national funds from FCT/MCTES (UID/Multi/04378/2019). It is also acknowledged the funding of CENIMAT by FEDER through the program COMPETE 2020 and National Funds through FCT-Portuguese Foundation for Science and Technology, under the project UID/CTM/50025/2019).

Acknowledgments: The authors acknowledge BYK Additives \& Instruments for donating the sodium montmorillonite (Cloisite ${ }^{\circledR} \mathrm{Na}+$ ).

Conflicts of Interest: The authors declare no conflict of interest. The founding sponsors had no role in the design of the study; in the collection, analyses, or interpretation of data; in the writing of the manuscript, and in the decision to publish the results.

\section{References}

1. Hassan, B.; Chatha, S.A.S.; Hussain, A.I.; Zia, K.M.; Akhtar, N. Recent advances on polysaccharides, lipids and protein based edible films and coatings: A review. Int. J. Biol. Macromol. 2018, 109, 1095-1107. [CrossRef] [PubMed]

2. Azeredo, H.M.C. De Nanocomposites for food packaging applications. Food Res. Int. 2009, 42, $1240-1253$. [CrossRef]

3. Vilarinho, F.; Andrade, M.; Buonocore, G.G.; Stanzione, M.; Vaz, M.F.; Sanches Silva, A. Monitoring lipid oxidation in a processed meat product packaged with nanocomposite poly(lactic acid) film. Eur. Polym. J. 2018, 98, 362-367. [CrossRef]

4. Fernando, A.L.; Duarte, M.P.; Vatsanidou, A.; Alexopoulou, E. Environmental aspects of fiber crops cultivation and use. Ind. Crops Prod. 2015, 68, 105-115. [CrossRef]

5. Ferreira, A.R.V.; Torres, C.A.V.; Freitas, F.; Sevrin, C.; Grandfils, C.; Reis, M.A.M.; Alves, V.D.; Coelhoso, I.M. Development and characterization of bilayer films of FucoPol and chitosan. Carbohydr. Polym. 2016, 147, 8-15. [CrossRef] [PubMed]

6. Souza, V.G.L.; Pires, J.R.A.; Vieira, É.T.; Coelhoso, I.M.; Duarte, M.P.; Fernando, A.L. Activity of chitosan-montmorillonite bionanocomposites incorporated with rosemary essential oil: From in vitro assays to application in fresh poultry meat. Food Hydrocoll. 2019, 89, 241-252. [CrossRef]

7. Souza, V.G.L.; Fernando, A.L. Nanoparticles in food packaging: Biodegradability and potential migration to food-A review. Food Packag. Shelf Life 2016, 8, 63-70. [CrossRef]

8. Pires, J.R.A.; de Souza, V.G.L.; Fernando, A.L. Chitosan/montmorillonite bionanocomposites incorporated with rosemary and ginger essential oil as packaging for fresh poultry meat. Food Packag. Shelf Life 2018, 17, 142-149. [CrossRef]

9. Siripatrawan, U.; Noipha, S. Active film from chitosan incorporating green tea extract for shelf life extension of pork sausages. Food Hydrocoll. 2012, 27, 102-108. [CrossRef]

10. Dutta, P.K.; Tripathi, S.; Mehrotra, G.K.; Dutta, J. Perspectives for chitosan based antimicrobial films in food applications. Food Chem. 2009, 114, 1173-1182. [CrossRef]

11. Darder, M.; Colilla, M.; Ruiz-Hitzky, E. Biopolymer-Clay Nanocomposites Based on Chitosan Intercalated in Montmorillonite. Chem. Mater. 2003, 15, 3774-3780. [CrossRef]

12. Sánchez-González, L.; Cháfer, M.; Hernández, M.; Chiralt, A.; González-Martínez, C. Antimicrobial activity of polysaccharide films containing essential oils. Food Control 2011, 22, 1302-1310. [CrossRef]

13. Chivrac, F.; Pollet, E.; Avérous, L. Progress in nano-biocomposites based on polysaccharides and nanoclays. Mater. Sci. Eng. R Reports 2009, 67, 1-17. [CrossRef]

14. Alizadeh, V.; Barzegar, H.; Nasehi, B.; Samavati, V. Development of a chitosan-montmorillonite nanocomposite film containing Satureja hortensis essential oil. Iran. Food Sci. Technol. Res. J. 2018, 13, 131-143. [CrossRef]

15. Abdollahi, M.; Rezaei, M.; Farzi, G. Influence of chitosan/clay functional bionanocomposite activated with rosemary essential oil on the shelf life of fresh silver carp. Int. J. Food Sci. Technol. 2014, 49, 811-818. [CrossRef] 
16. Souza, V.G.L.; Pires, J.R.A.; Rodrigues, P.F.; Lopes, A.A.S.; Fernandes, F.M.B.; Duarte, M.P.; Coelhoso, I.M.; Fernando, A.L. Bionanocomposites of chitosan/montmorillonite incorporated with Rosmarinus officinalis essential oil: Development and physical characterization. Food Packag. Shelf Life 2018, 16, 148-156. [CrossRef]

17. Souza, V.G.L.; Rodrigues, P.F.; Duarte, M.P.; Fernando, A.L. Antioxidant Migration Studies in Chitosan Films Incorporated with Plant Extracts. J. Renew. Mater. 2018, 6, 548-558. [CrossRef]

18. Regnier, T.; Combrinck, S.; Du Plooy, W. Essential Oils and Other Plant Extracts as Food Preservatives. In Progress in Food Preservation; Wiley-Blackwell: Oxford, UK, 2012; pp. 539-579.

19. Pascoal, A.; Quirantes-Piné, R.; Fernando, A.L.; Alexopoulou, E.; Segura-Carretero, A. Phenolic composition and antioxidant activity of kenaf leaves. Ind. Crops Prod. 2015, 78, 116-123. [CrossRef]

20. Souza, V.G.L.; Rodrigues, C.; Ferreira, L.; Pires, J.R.A.; Duarte, M.P.; Coelhoso, I.; Fernando, A.L. In vitro bioactivity of novel chitosan bionanocomposites incorporated with different essential oils. Ind. Crops Prod. 2019, 140, 111563. [CrossRef]

21. Appendini, P.; Hotchkiss, J.H. Review of antimicrobial food packaging. Innov. Food Sci. Emerg. Technol. 2002, 3, 113-126. [CrossRef]

22. Pola, C.C.; Medeiros, E.A.A.; Pereira, O.L.; Souza, V.G.L.; Otoni, C.G.; Camilloto, G.P.; Soares, N.F.F. Cellulose acetate active films incorporated with oregano (Origanum vulgare) essential oil and organophilic montmorillonite clay control the growth of phytopathogenic fungi. Food Packag. Shelf Life 2016, 9, 69-78. [CrossRef]

23. Atarés, L.; Chiralt, A. Essential oils as additives in biodegradable films and coatings for active food packaging. Trends Food Sci. Technol. 2016, 48, 51-62. [CrossRef]

24. Ribeiro-Santos, R.; Andrade, M.; de Melo, N.R.; Sanches-Silva, A. Use of essential oils in active food packaging: Recent advances and future trends. Trends Food Sci. Technol. 2017, 61, 132-140. [CrossRef]

25. Noori, S.; Zeynali, F.; Almasi, H. Antimicrobial and antioxidant efficiency of nanoemulsion-based edible coating containing ginger (Zingiber officinale) essential oil and its effect on safety and quality attributes of chicken breast fillets. Food Control 2018, 84, 312-320. [CrossRef]

26. Silva, F.; Domingues, F.C.; Nerín, C. Trends in microbial control techniques for poultry products. Crit. Rev. Food Sci. Nutr. 2016, 58, 1-19. [CrossRef]

27. Souza, V.G.L.; Fernando, A.L.; Pires, J.R.A.; Rodrigues, P.F.; Lopes, A.A.S.; Fernandes, F.M.B. Physical properties of chitosan films incorporated with natural antioxidants. Ind. Crops Prod. 2017, 107, 565-572. [CrossRef]

28. Souza, V.G.L.; Pires, J.R.; Vieira, É.T.; Coelhoso, I.M.; Duarte, M.P.; Fernando, A.L. Shelf Life Assessment of Fresh Poultry Meat Packaged in Novel Bionanocomposite of Chitosan/Montmorillonite Incorporated with Ginger Essential Oil. Coatings 2018, 8, 177. [CrossRef]

29. Woranuch, S.; Yoksan, R. Eugenol-loaded chitosan nanoparticles: II. Application in bio-based plastics for active packaging. Carbohydr. Polym. 2013, 96, 586-592. [CrossRef]

30. Higueras, L.; López-carballo, G.; Cerisuelo, J.P.; Gavara, R. Preparation and characterization of chitosan/HP- $\beta$-cyclodextrins composites with high sorption capacity for carvacrol. Carbohydr. Polym. 2012, 97, 262-268. [CrossRef]

31. ASTM-America Society Standard Testing and Materials. Standard Test Method for Tensile Properties of Thin Plastic Sheeting-D882-12; ASTM: West Conshohocken, PA, USA, 2012; p. 12.

32. Pastor, C.; Sánchez-González, L.; Chiralt, A.; Cháfer, M.; González-Martínez, C. Physical and antioxidant properties of chitosan and methylcellulose based films containing resveratrol. Food Hydrocoll. 2013, 30, $272-280$. [CrossRef]

33. Park, S.-I.; Zhao, Y. Incorporation of a high concentration of mineral or vitamin into chitosan-based films. J. Agric. Food Chem. 2004, 52, 1933-1939. [CrossRef] [PubMed]

34. Kanatt, S.R.; Rao, M.S.; Chawla, S.P.; Sharma, A. Active chitosan-polyvinyl alcohol films with natural extracts. Food Hydrocoll. 2012, 29, 290-297. [CrossRef]

35. Alves, V.D.; Costa, N.; Coelhoso, I.M. Barrier properties of biodegradable composite films based on kappa-carrageenan/pectin blends and mica flakes. Carbohydr. Polym. 2010, 79, 269-276. [CrossRef]

36. Lavorgna, M.; Piscitelli, F.; Mangiacapra, P.; Buonocore, G.G. Study of the combined effect of both clay and glycerol plasticizer on the properties of chitosan films. Carbohydr. Polym. 2010, 82, 291-298. [CrossRef] 
37. Dias, M.V.; Machado Azevedo, V.; Borges, S.V.; Soares, N.D.F.F.; de Barros Fernandes, R.V.; Marques, J.J.; Medeiros, É.A.A. Development of chitosan/montmorillonite nanocomposites with encapsulated $\alpha$-tocopherol. Food Chem. 2014, 165, 323-329. [CrossRef]

38. Wang, S.F.; Shen, L.; Tong, Y.J.; Chen, L.; Phang, I.Y.; Lim, P.Q.; Liu, T.X. Biopolymer chitosan/montmorillonite nanocomposites: Preparation and characterization. Polym. Degrad. Stab. 2005, 90, 123-131. [CrossRef]

39. Silva-Weiss, A.; Bifani, V.; Ihl, M.; Sobral, P.J.A.; Gómez-Guillén, M.C. Structural properties of films and rheology of film-forming solutions based on chitosan and chitosan-starch blend enriched with murta leaf extract. Food Hydrocoll. 2013, 31, 458-466. [CrossRef]

40. Ávila, A.; Bierbrauer, K.; Pucci, G.; López-González, M.; Strumia, M. Study of optimization of the synthesis and properties of biocomposite films based on grafted chitosan. J. Food Eng. 2012, 109, 752-761. [CrossRef]

41. Bonilla, J.; Sobral, P.J.A. Investigation of the physicochemical, antimicrobial and antioxidant properties of gelatin-chitosan edible film mixed with plant ethanolic extracts. Food Biosci. 2016, 16, 17-25. [CrossRef]

42. Qin, Y.Y.; Zhang, Z.H.; Li, L.; Yuan, M.L.; Fan, J.; Zhao, T.R. Physio-mechanical properties of an active chitosan film incorporated with montmorillonite and natural antioxidants extracted from pomegranate rind. J. Food Sci. Technol. 2015, 52, 1471-1479. [CrossRef]

43. Sun, L.; Sun, J.; Chen, L.; Niu, P.; Yang, X.; Guo, Y. Preparation and characterization of chitosan film incorporated with thinned young apple polyphenols as an active packaging material. Carbohydr. Polym. 2017, 163, 81-91. [CrossRef] [PubMed]

44. Acevedo-Fani, A.; Salvia-Trujillo, L.; Rojas-Graü, M.A.; Martín-Belloso, O. Edible films from essential-oil-loaded nanoemulsions: Physicochemical characterization and antimicrobial properties. Food Hydrocoll. 2015, 47, 168-177. [CrossRef]

45. Sakurai, K.; Maegawa, T.; Takahashi, T. Glass transition temperature of chitosan and miscibility of chitosan/poly(N-vinyl pyrrolidone) blends. Polymer 2000, 41, 7051-7056. [CrossRef]

46. Woranuch, S.; Yoksan, R. Eugenol-loaded chitosan nanoparticles: I. Thermal stability improvement of eugenol through encapsulation. Carbohydr. Polym. 2013, 96, 578-585. [CrossRef] [PubMed]

47. Tongnuanchan, P.; Benjakul, S.; Prodpran, T. Physico-chemical properties, morphology and antioxidant activity of film from fish skin gelatin incorporated with root essential oils. J. Food Eng. 2013, 117, 350-360. [CrossRef]

48. Noshirvani, N.; Ghanbarzadeh, B.; Gardrat, C.; Rezaei, M.R.; Hashemi, M.; Le Coz, C.; Coma, V. Cinnamon and ginger essential oils to improve antifungal, physical and mechanical properties of chitosan-carboxymethyl cellulose films. Food Hydrocoll. 2017, 70, 36-45. [CrossRef]

49. Lewandowska, K.; Sionkowska, A.; Kaczmarek, B.; Furtos, G. Characterization of chitosan composites with various clays. Int. J. Biol. Macromol. 2014, 65, 534-541. [CrossRef]

50. Rimdusit, S.; Jingjid, S.; Damrongsakkul, S.; Tiptipakorn, S.; Takeichi, T. Biodegradability and property characterizations of Methyl Cellulose: Effect of nanocompositing and chemical crosslinking. Carbohydr. Polym. 2008, 72, 444-455. [CrossRef]

51. Beigzadeh Ghelejlu, S.; Esmaiili, M.; Almasi, H. Characterization of chitosan-nanoclay bionanocomposite active films containing milk thistle extract. Int. J. Biol. Macromol. 2016, 86, 613-621. [CrossRef]

52. Perdones, Á.; Vargas, M.; Atarés, L.; Chiralt, A. Physical, antioxidant and antimicrobial properties of chitosan-cinnamon leaf oil films as affected by oleic acid. Food Hydrocoll. 2014, 36, 256-264. [CrossRef]

53. Peng, Y.; Li, Y. Combined effects of two kinds of essential oils on physical, mechanical and structural properties of chitosan films. Food Hydrocoll. 2014, 36, 287-293. [CrossRef]

54. Wang, Y.; Xia, Y.; Zhang, P.; Ye, L.; Wu, L.; He, S. Physical Characterization and Pork Packaging Application of Chitosan Films Incorporated with Combined Essential Oils of Cinnamon and Ginger. Food Bioprocess Technol. 2017, 10, 503-511. [CrossRef]

55. Sarantópoulos, C.G.L.; Oliveira, L.M.; Padula, M.; Coltro, L.; Aalves, R.M.V.; Garcia, E.C. Embalagens Plásticas Flexíveis: Principais Polímeros e Avaliação de Propriedades; CETEA/ITAL: Campinas, Brazil, 2002; p. 267.

56. Russo, T.; D’Amora, U.; Gloria, A.; Tunesi, M.; Sandri, M.; Rodilossi, S.; Albani, D.; Forloni, G.; Giordano, C.; Cigada, A.; et al. Systematic analysis of injectable materials and 3D rapid prototyped magnetic scaffolds: From CNS applications to soft and hard tissue repair/regeneration. Procedia Eng. 2013, 59, 233-239. [CrossRef]

57. Atarés, L.; Bonilla, J.; Chiralt, A. Characterization of sodium caseinate-based edible films incorporated with cinnamon or ginger essential oils. J. Food Eng. 2010, 100, 678-687. [CrossRef] 
58. Aguirre, A.; Borneo, R.; León, A.E. Antimicrobial, mechanical and barrier properties of triticale protein films incorporated with oregano essential oil. Food Biosci. 2013, 1, 2-9. [CrossRef]

59. Zeid, A.; Karabagias, I.K.; Nassif, M.; Kontominas, M.G. Preparation and evaluation of antioxidant packaging films made of polylactic acid containing thyme, rosemary, and oregano essential oils. J. Food Process. Preserv. 2019, 1-11. [CrossRef]

60. Moradi, M.; Tajik, H.; Razavi Rohani, S.M.; Oromiehie, A.R.; Malekinejad, H.; Aliakbarlu, J.; Hadian, M. Characterization of antioxidant chitosan film incorporated with Zataria multiflora Boiss essential oil and grape seed extract. LWT Food Sci. Technol. 2012, 46, 477-484. [CrossRef]

61. Siripatrawan, U.; Harte, B.R. Physical properties and antioxidant activity of an active film from chitosan incorporated with green tea extract. Food Hydrocoll. 2010, 24, 770-775. [CrossRef]

62. Nunes, C.; Maricato, É.; Cunha, Â.; Nunes, A.; da Silva, J.A.L.; Coimbra, M.A. Chitosan-caffeic acid-genipin films presenting enhanced antioxidant activity and stability in acidic media. Carbohydr. Polym. 2013, 91, 236-243. [CrossRef]

63. Hafsa, J.; Smach, M.A.; Ben Khedher, M.R.; Charfeddine, B.; Limem, K.; Majdoub, H.; Rouatbi, S. Physical, antioxidant and antimicrobial properties of chitosan films containing Eucalyptus globulus essential oil. LWT Food Sci. Technol. 2016, 68, 356-364. [CrossRef]

64. Abdollahi, M.; Rezaei, M.; Farzi, G. A novel active bionanocomposite film incorporating rosemary essential oil and nanoclay into chitosan. J. Food Eng. 2012, 111, 343-350. [CrossRef]

65. Contini, C.; Katsikogianni, M.G.; O’Neill, F.T.; O'Sullivan, M.; Dowling, D.P.; Monahan, F.J. Development of active packaging containing natural antioxidants. Procedia Food Sci. 2011, 1, 224-228. [CrossRef]

66. Soares, F.; Pires, A.C.S.; Camilloto, G.P.; Santiago-Silva, P.; Espitia, P.J.P.; Silva, W.A. Recent patents on active packaging for food application. Recent Pat. Food. Nutr. Agric. 2009, 1, 171-178. [CrossRef]

67. Miller, K.S.; Krochta, J.M. Oxygen and aroma barrier properties of edible films: A review. Trends Food Sci. Technol. 1997, 8, 228-237. [CrossRef]

68. Atarés, L.; Pérez-Masiá, R.; Chiralt, A. The role of some antioxidants in the HPMC film properties and lipid protection in coated toasted almonds. J. Food Eng. 2011, 104, 649-656. [CrossRef]

69. Baldwin, E.A.; Hagenmaier, R.D.; Bai, J. Edible Coatings and Films to Improve Food Quality; CRC Press: Boca Raton, FL, USA, 2012; ISBN 9781138198937.

70. Nouri, A.; Yaraki, M.T.; Ghorbanpour, M.; Agarwal, S.; Gupta, V.K. Enhanced Antibacterial effect of chitosan film using Montmorillonite/CuO nanocomposite. Int. J. Biol. Macromol. 2017, 109, 1219-1231. [CrossRef]

71. Cerisuelo, J.P.; Alonso, J.; Aucejo, S.; Gavara, R.; Hernández-Muñoz, P. Modifications induced by the addition of a nanoclay in the functional and active properties of an $\mathrm{EVOH}$ film containing carvacrol for food packaging. J. Memb. Sci. 2012, 423, 247-256. [CrossRef]

(C) 2019 by the authors. Licensee MDPI, Basel, Switzerland. This article is an open access article distributed under the terms and conditions of the Creative Commons Attribution (CC BY) license (http://creativecommons.org/licenses/by/4.0/). 